\title{
Chemosystematic Evaluation of Some Nigerian Gossypium hirsutum L. Using Qualitative and Quantitative Phytochemical Analysis
}

\author{
DANZAKI MUHAMMAD MUAZU*1, MUSTAPHA OBA TOYIN² \& ABDULKAREEM KHADIJA \\ ABDULHAMID $^{2}$ \\ ${ }^{1}$ Department of Biology, Nigerian Army University Biu, Biu, Nigeria; ${ }^{2}$ Department of Plant Biology, University of \\ Ilorin, Ilorin, Nigeria \\ *Corresponding author: mmdz581@gmail.com \\ Received: 03 November $2020 \quad$ Accepted: 31 May 2021 \\ Published: 30 June 2021
}

\begin{abstract}
There is little information on the use of phytochemicals for the systematic study of variation and resolving relatedness in Nigerian Gossypium hirsutum species. Thus, there is a need to carry out detailed phytochemical studies of the plant leaves, which could be helpful in ascertaining their diversity and relatedness. The qualitative and quantitative phytochemical screening was conducted on 18 accessions of G. hirsutum using the established laboratory protocols. The findings of this study indicated the presence of tannin, alkaloids, proline, flavonoids, and saponin in all of the accessions that were grouped into two at $17 \%$ genetic distance, indicating $83 \%$ relatedness. However, phytosterol, terpenoids and glycosides were absent in three of the accessions, which were grouped at $48 \%$. The phytochemical compositions were tannin $(1.30-1.09 \mathrm{mg} / 100$ $\mathrm{g})$, flavonoid (1.60-1.16 mg/100 g, terpenoid (0.42-0.35 mg/100 g), alkaloid (1.47-1.11 mg/100 g), saponin (4.86-1.59 $\mathrm{mg} / 100 \mathrm{~g})$, glycoside $(1.02-0.88 \mathrm{mg} / 100 \mathrm{~g})$, proline $(1.57-1.0 \mathrm{mg} / 100 \mathrm{~g})$ and phytosterol $(0.36-0.2 \mathrm{mg} / 100 \mathrm{~g})$. The aim of this research was to determine the diversity and relatedness of $G$. hirsutum genotypes collected from different locations of Nigeria. In general, this study emphasises the use of plant chemicals for classification purposes.
\end{abstract}

Keywords: Diversity, Gossypium hirsutum, phytochemicals

Copyright: This is an open access article distributed under the terms of the CC-BY-NC-SA (Creative Commons Attribution-NonCommercial-ShareAlike 4.0 International License) which permits unrestricted use, distribution, and reproduction in any medium, for non-commercial purposes, provided the original work of the author(s) is properly cited.

\section{INTRODUCTION}

Gossypium hirsutum belongs to the genus Gossypium, family Malvaceae, or mallow family. It is native to tropical and subtropical regions of the world, including America, Africa, and India. Plants have naturally occurring chemical compounds referred to as phytochemicals. Zheng and Wang (2003) have reported various phytochemical molecules such as vitamins, terpenoids, phenolic acids, lignins, stilbenes, tannins, flavonoids, quinones, coumarins, alkaloids, amines, betalains, and other metabolites in plants, which are rich in antioxidant activity. These phytochemicals have been essentially used for classification purposes based on some plant features that include edibility, taste, colour, smell and medicinal value subjective to chemical properties (Jones \& Luchsinger, 1987). It is commonly accepted that certain compounds and related substances may be characteristics of a taxonomic group (Wink \& Waterman, 1999). The use of phytochemicals for chemotaxonomic purposes has been employed at all levels of the taxonomic hierarchy (Singh, 2016). It was reported that when a group indicate differences in its content. It is by virtue of its ability to form a chemical substance by metabolic processes retained by the group or its ancestors (Umoh, 2020). Thus, the sequence of chemical evolution is seen to be established in order to offer insight to the evolutionary history of the group, as well as to the understanding of the present day relationships within and between groups (Davis \& Heywood, 1963). The phenolics, alkaloids, terpenoids, and non-protein amino acids are among the important and widely exploited groups of compounds utilised for chemotaxonomic classification (Stace, 1980). These groups of compounds exhibit a wide variation in chemical diversity, distribution and function (Smith, 1976; Hegnauer, 1986). The system of chemotaxonomic classification relies on the chemical similarity of taxon (Atal, 1982).

Ayeni et al. (2015) reported the presence of alkaloids, saponins, flavonoids, tannins and cardiac glycosides in G. hirsutum. Chandrashekar et al. (2013) also observed the presence of phenols, glycosides, flavonoids, and steroids in G. hirsutum. 
However, phytochemicals like saponins, flavonoids, tri-terpenoids and tannins were not reported.Most of these studies on phytochemicals were for medicinal purposes. There is also little information on the use of phytochemicals for resolving diversity in Nigerian G. hirsutum species. Therefore, there is a need to carry out detailed phytochemical studies of the plant leaves, which could ascertain their diversity and relatedness.

\section{MATERIALS AND METHODS}

The G. hirsutum accessions were collected from Institute of Agricultural Research (IAR), Zaria, Kaduna State, National Center for Genetic Research and Biotechnology (NACGRAB), Ibadan, Oyo State, Dangote Ginnery, Kankara, Katsina state, Nigeria and farmers' fields in five states of savanna and rainforest zones of Nigeria (Table 1). The accessions collected from the field were identified in the Department of Plant Biology Herbarium, University of Ilorin, Iorin, Nigeria.

\section{Phytochemical Screening}

The leaves of the plants were air dried and ground into uniform powder using a Thomas-Wiley milling machine. The aqueous extract of each sample of the genotypes was prepared by soaking $100 \mathrm{~g}$ of dried powdered sample in $200 \mathrm{~mL}$ of distilled water for 12 hrs. The extract was filtered using Whatman filter paper No. $42(125 \mathrm{~mm})$. The standard procedure in identifying chemical constituents as described by Sofowora (1993), Trease and Evans (1989) on tannins, saponin, flavonoid, steroids, terpenoids, phenol, alkaloids and glycosides were employed.

\section{Qualitative Phytochemical Screening}

Test for tannins was done by boiling $0.5 \mathrm{~g}$ of powdered sample in $20 \mathrm{~mL}$ of water in a test tube and then filtered. A few drops of $0.1 \%$ ferric chloride were added. The manifestation of a brownish green or a blue-black colouration shows the presence of tannin.

For saponin, test was carried out by boiling $2 \mathrm{~g}$ of powdered sample in $20 \mathrm{~mL}$ of distilled water in a water bath and filtered. A stable persistent froth was obtained by mixing $10 \mathrm{~mL}$ of the filtrate in $5 \mathrm{~mL}$ of distilled water after shaking thoroughly. A mixture of the froth with three drops of olive oil is then observed for the formation of emulsion.

Test for flavonoid was performed as reported by Sofowara (1993) and Harbourne (1973). A $5 \mathrm{~g}$ of powdery sample was heated with $10 \mathrm{~mL}$ of ethyl acetate in a closed container over a steam bath for 30 minutes. The mixture was filtered and $4 \mathrm{~mL}$ of the filtrate was shaken with $5 \mathrm{~mL}$ of $1.0 \mathrm{M}$ dilute ammonia solution and $5 \mathrm{~mL}$ of concentrated sulfuric acid. A yellow colouration was observed indicating the presence of flavonoid.

Table 1. Areas for Gossypium hirsutum collection

\begin{tabular}{|c|c|c|c|c|c|}
\hline Serial & $\begin{array}{l}\text { Code for } \\
\text { Location }\end{array}$ & Collection Site & $\begin{array}{l}\text { State of } \\
\text { Collection }\end{array}$ & Type of Environment & Accession Type \\
\hline 1. & $\mathrm{KR}$ & Kankara & Katsina & Tropical, monsoon & Landraces \\
\hline 2. & $\mathrm{~KB}$ & Kabomo & Katsina & Tropical, monsoon & Landraces \\
\hline 3. & GS & Gusau & Zamfara & Tropical, monsoon & Landraces \\
\hline 4. & YG & Yargoje & Katsina & Tropical, monsoon & Landraces \\
\hline 5. & YB & Dangote Ginnery & Katsina & Tropical, monsoon & Hybrid \\
\hline 6. & NGB01 & NACGRAB & Oyo & Tropical, savannah & Hybrid \\
\hline 7. & NGB02 & NACGRAB & Oyo & Tropical, savannah & Hybrid \\
\hline 8. & $\mathrm{KC}$ & Dangote Ginnery & Katsina & Tropical, monsoon & Hybrid \\
\hline 9. & $\mathrm{AD}$ & Mubi & Adamawa & Tropical, savannah & Landraces \\
\hline 10. & AD1 & Mubi & Adamawa & Tropical, savannah & Landraces \\
\hline 11. & FT & Funtua & Katsina & Tropical, monsoon & Landraces \\
\hline 12. & $\mathrm{BK}$ & Bakori & Katsina & Tropical, monsoon & Landraces \\
\hline 13. & $\mathrm{ABK}$ & Abeokuta & Ogun & Tropical, savannah & Landraces \\
\hline 14. & GS1 & Gusau & Zamfara & Tropical, monsoon & Landraces \\
\hline 15. & GS2 & Gusau & Zamfara & Tropical, monsoon & Landraces \\
\hline 16. & $\mathrm{SC} 8$ & IAR & Kaduna & Tropical, monsoon & Hybrid \\
\hline 17. & SC9 & IAR & Kaduna & Tropical, monsoon & Hybrid \\
\hline 18. & $\mathrm{KN}$ & Gwarzo & Kano & Tropical, monsoon & Landraces \\
\hline
\end{tabular}


For steroids, test was carried out using the method described by Ejikeme et al. (2014). Powdered sample $(0.50 \mathrm{~g})$ were weighed into a beaker and mixed with $20 \mathrm{~mL}$ of ethanol; the component was extracted for 2 hours. Acetic anhydride $(2 \mathrm{~mL})$ and a $2 \mathrm{~mL} \mathrm{H}_{2} \mathrm{SO}_{4}$ were added to $5 \mathrm{~g}$ of the ethanolic extract. The colour changed from violet to blue in some samples which indicated the presence of steroids.

Test for terpenoids was performed by mixing about $0.5 \mathrm{~g}$ of powdered sample with chloroform (2 $\mathrm{mL})$ and concentrated $\mathrm{H}_{2} \mathrm{SO}_{4}(3 \mathrm{~mL})$ were added to form a layer. A colouration of reddish brown at the interface indicated the presence of terpenoids.

For phenol, test was carried out by soaking finely ground sample $(1 \mathrm{~g})$ in $25 \mathrm{~mL}$ of $2 \%$ of $\mathrm{HCl}$ for 1 hour and then filtered through $10 \mathrm{~cm}$ Whatman No. 1 filter paper. $5 \mathrm{~mL}$ of each plant extract was mixed with $1 \mathrm{~mL}$ of $0.30 \%$ Ammonium thiocyanate solution and few drops of $0.1 \%$ ferric chloride solution. A brownish yellow colour indicates the presence of phenol.

Determination of alkaloids was done using method described by Harborne (1993). $5 \mathrm{~g}$ of the powdered sample was weighed into $250 \mathrm{~mL}$ beaker and $200 \mathrm{~mL} 10 \%$ acetic acid in ethanol was added. Then, the solution mixture was filtered using Whatman filter paper No. $42(125 \mathrm{~mm})$. The extract was made alkaline using $5 \mathrm{~mL}$ of $28 \%$ ammonia solution $\left(\mathrm{NH}_{3}\right)$ in a separating funnel. Equal volume of chloroform $(5.0 \mathrm{~mL})$ was used in further solution extraction in which chloroform solution was extracted with two $5 \mathrm{~mL}$ portions of $1.0 \mathrm{M}$ dilute sulfuric acid. This final acid extract was then used to carry out the following test using $0.5 \mathrm{~mL}$ of Dragendorff's reagent (Bismuth potassium iodide solution) that was mixed with $2 \mathrm{~mL}$ of acid extract. The formation of orange precipitate indicates the presence of alkaloid.

Determination of glycosides was done using the following procedure. Alcoholic extracts were obtained by soaking the powdered samples separately in $100 \mathrm{~mL}$ of different solvents such as methanol, ethanol, chloroform and hot water in conical flasks and then subjected to agitation on a rotary magnetic shaker for about 72 hours. After three days the extracts were filtered with No. 42 Whatman filter paper. These extracts were preserved in sterilised air tight labeled bottles in a refrigerator at $4{ }^{\circ} \mathrm{C}$ until further use. Glycoside was determined by adding $2 \mathrm{~mL}$ of chloroform to $1 \mathrm{~mL}$ of alcoholic extract and sulfuric acid $\left(\mathrm{H}_{2} \mathrm{SO}_{4}\right)$ was carefully added to form a lower layer. A reddish brown colouration at the interface indicates the presence of steroidal rings (Odebiyi \& Sofowora, 1979).

\section{Statistical Analysis}

The level of significant difference between mean values of each phytochemical component in plant samples under study was confirmed using one-way ANOVA at $95 \%$ confidence interval.

\section{Quantitative Phytochemical Analysis}

Further quantification of the phytochemical constituents in the samples was determined using the standard procedures as follows.

Determination of the quantity of alkaloids was done using method described by Harbourne (1973). The powdered extracts weighing $2 \mathrm{~g}$ was poured in a $250 \mathrm{~mL}$ beaker, then $80 \mathrm{~mL}$ of $10 \%$ acetic acid in ethanol was added, covered and allowed to stand for 4 hours. This was then filtered and concentrated on a water bath to one-quarter of the original volume. The concentrated ammonium was then added in drops to the extract until precipitation was complete. The solution was collected and allowed to settle. Then the precipitate was collected and washed with dilute ammonium hydroxide and filtered. The residue obtained was dried and weighed.

Determination of the quantity of saponins was carried out as described by Obadoni and Ochuko (2001). Powdered extract ( $2 \mathrm{~g})$ was poured into a conical flask and $20 \mathrm{~mL}$ of $20 \%$ aqueous ethanol was added. It was then heated over the water bath for 4 hours with continuous stirring at $55^{\circ} \mathrm{C}$. This mixture was then filtered and the residue was re-extracted with another $200 \mathrm{~mL}$ of $20 \%$ ethanol. This concentrate was transferred into a $250 \mathrm{~mL}$ separator funnel and $20 \mathrm{~mL}$ of diethyl ether was added and shaken vigorously. The aqueous layer was recovered while the ether layer was discarded. The purification process was repeated and $60 \mathrm{~mL}$ of $\mathrm{n}$-butanol was added. The combined n-butanol extracts were washed twice with $10 \mathrm{~mL}$ of $5 \%$ aqueous sodium chloride. The remaining solution was heated in the water bath. After evaporation the sample was dried in the oven to a constant weight. 
Determination of the quantity of tannins was performed according to Van-Burden and Robinson (1969). A $500 \mathrm{mg}$ extract was weighed into a $50 \mathrm{~mL}$ plastic bottle. Distilled water $(50 \mathrm{~mL})$ was added and then shaken vigorously on a mechanical shaker for one hour. This was then filtered into a $50 \mathrm{~mL}$ volumetric flask and made up to the mark. The filtrate $(5 \mathrm{~mL})$ was pipetted out into a test tube and mixed with $2 \mathrm{~mL}$ of $0.1 \mathrm{M} \mathrm{FeCl}_{3}$ in $0.1 \mathrm{~N} \mathrm{HCl}$ and $0.008 \mathrm{M}$ potassium ferrocyanide. The absorbance was measured, using ultraviolet spectrophotometry, at $120 \mathrm{~nm}$ within 10 minutes to get the total tannins.

Determination of the quantity of flavonoids was carried out using the method of Boham and KocipalAbyazan (1994). A 2 g extract were extracted repeatedly with $20 \mathrm{~mL}$ of $80 \%$ aqueous methanol at room temperature. The whole solution was filtered using filter paper No. $42(125 \mathrm{~mm})$. The filtrate was later transferred into a crucible and evaporated to dryness over a water bath and weighed to a constant weight, and the weight was calculated.

Determination of the quantity of phenolic compounds was done by spectrophotometric method. The extract $(100 \mathrm{mg})$ was weighed and dissolved in $100 \mathrm{~mL}$ of triple distilled water (TDW). Then $1 \mathrm{~mL}$ of this solution was transferred to a test tube and then $0.5 \mathrm{~mL} 2 \mathrm{~N}$ of the Folin-Ciocalteu reagent and $1.5 \mathrm{~mL} 20 \%$ of $\mathrm{Na}_{2} \mathrm{CO}_{3}$ solution was added and the volume was made up to $8 \mathrm{~mL}$ with TDW, followed by vigorous shaking and was made to stand for 2 hours. Then the absorbance was measured at $765 \mathrm{~nm}$ using spectrophotometre. The data was used to estimate the total phenolic content using a calibration curve obtained from various diluted concentrations of gallic acid.

Determination of glycoside was done according to method described by Amadi et al. (2004). Powdered sample weighing $1 \mathrm{~g}$ was placed into a $250 \mathrm{~mL}$ round bottom flask and about $200 \mathrm{~mL}$ of distilled water was added and allowed to stand for 2 hours for autolysis to occur. Full distillation was carried out in a $250 \mathrm{~mL}$ conical flask containing 20 $\mathrm{mL}$ of $2.5 \% \mathrm{NaOH}$ in the sample after adding an antifoaming agent (tannic acid). Cyanogenic glycoside $(100 \mathrm{~mL}), 8 \mathrm{~mL}$ of $6 \mathrm{M} \mathrm{NH}_{4} \mathrm{OH}$, and $2 \mathrm{~mL}$ of $5 \% \mathrm{KI}$ (potassium iodide) were added to the distillate(s), mixed, and titrated with $0.02 \mathrm{M} \mathrm{AgNO}_{3}$ (silver nitrate) using a microburette against a black background. The continuous turbidity indicates the end point of the titration. The glycoside content in the sample was calculated as glycoside $(\mathrm{mg} / 100 \mathrm{~g})=$ titre value $(\mathrm{mL}) \times 1.08 \times$ exact volume/Aliquot volume $(\mathrm{mL}) \times$ sample weight $(\mathrm{g}) \times 100($ Smith et al., 2000).

\section{RESULTS}

The results of the phytochemical screening revealed the presence of tannin, alkaloids, proline, flavonoids, phytosterol and saponin. Terpenoids, glycosides and phytosterol were present in almost all the accessions but absent in $\mathrm{KR}, \mathrm{BK}$ and $\mathrm{AD}$. Phytobiotin was absent in all the accessions studied (Table 2). Variations were observed in the quantity of the phytochemicals present. Significant differences $(\mathrm{p} \leq 0.05)$ exist among the various quantitative values (Table 3). The highest tannin content was recorded in SC9 $(1.30 \mathrm{mg})$ while the least was in $\mathrm{KN}(1.09 \mathrm{mg})$. The least flavonoid value was obtained by $\mathrm{AD}(1.15 \mathrm{mg})$ while the highest was obtained by ABK (1.6 mg) followed by AD1 (1.56 $\mathrm{mg}$ ). The highest terpenoid content was obtained in ABK $(0.4 \mathrm{mg})$ while YG had the least content with $0.35 \mathrm{mg}$. SC9 had the highest alkaloid content at $1.47 \mathrm{mg}$, while $\mathrm{KN}(1.11 \mathrm{mg})$ had the least alkaloid content. The accession AD1 (4.42 mg) had the highest saponin content while KN $(1.59 \mathrm{mg})$ had the least saponin content. SC9 $(1.09 \mathrm{mg})$ had the highest glycoside content while $\mathrm{KB}(0.88 \%)$ obtained the least glycoside content. The highest proline content was obtained by SC $8(1.57 \mathrm{mg})$ while $\mathrm{KN}(0.93 \mathrm{mg})$ obtained the least proline content. YG $(0.36 \mathrm{mg})$ obtained the highest phytosterol content while SC9 and NG2 had the least phytosterol content at $0.2 \mathrm{mg}$, respectively.

\section{Cluster Analysis Based on Phytochemical Studies}

The UPGMA (Ward's method) clustering, based on the phytochemical traits screened, was able to separate the eighteen accessions into two groups I and II (Figure 1). These two groups were further subdivided into two clusters each Ia and IIb. Cluster Ia consist of three accessions ( $\mathrm{KN}, \mathrm{AD}$ and $\mathrm{BK}$.). These accessions that were sourced from different locations, from the farmers' fields clustered together to show similarity phytochemically. Cluster I comprised of a group consisting of $\mathrm{AD}$ and $\mathrm{BK}$ accessions while $\mathrm{KN}$ is a subcluster. The second cluster consisted of six groups and three independent groups. GS, GS2 and KB formed independent groups. AD and $\mathrm{BK}$ are closely related. $\mathrm{SC} 9$ and $\mathrm{SC} 8$ were similar according to their phytochemical attributes. These were collected from same seed bank and are hybrids. Accessions GS1, KR, YG and 
Table 2. Qualitative phytochemical composition in 18 accessions of Gossypium hirsutum

\begin{tabular}{|c|c|c|c|c|c|c|c|c|c|}
\hline Accession & Alkaloids & Phytobiotin & Glycosides & Saponins & Phytosterols & Terpenoid & Tannins & Flavonoids & Proline \\
\hline $\mathrm{KB}$ & + & - & + & + & + & + & + & + & + \\
\hline YG & + & - & + & + & + & + & + & + & + \\
\hline $\mathrm{KR}$ & + & - & + & + & + & + & + & + & + \\
\hline BK & + & - & - & + & - & - & + & + & + \\
\hline YB & + & - & + & + & + & + & + & + & + \\
\hline SC9 & + & - & + & + & + & + & + & + & + \\
\hline SC8 & + & - & + & + & + & + & + & + & + \\
\hline AD1 & + & - & + & + & + & + & + & + & + \\
\hline $\mathrm{KN}$ & + & - & - & + & - & - & + & + & + \\
\hline FT & + & - & + & + & + & + & + & + & + \\
\hline $\mathrm{AD}$ & + & - & - & + & - & - & + & + & + \\
\hline GS & + & - & + & + & + & + & + & + & + \\
\hline GS1 & + & - & + & + & + & + & + & + & + \\
\hline GS2 & + & - & + & + & + & + & + & + & + \\
\hline $\mathrm{KC}$ & + & - & + & + & + & + & + & + & + \\
\hline NG1 & + & - & + & + & + & + & + & + & + \\
\hline NG2 & + & - & + & + & + & + & + & + & + \\
\hline $\mathrm{ABK}$ & + & - & + & + & + & + & + & + & + \\
\hline
\end{tabular}

Notes: $(+)=$ present $(-)=$ absent.

Table 3. Quantitative phytochemical composition in 18 accessions of Gossypium hirsutum

\begin{tabular}{lllllllll}
\hline Accession & Tannins & Flavonoids & Terpenoid & Alkaloids & Saponins & Glycoside & Proline & Phytosterols \\
\hline KN & $1.09 \pm 0.01$ & $1.16 \pm 0.01$ & Undetected & $1.11 \pm 0.01$ & $1.59 \pm 0.01$ & Undetected & $0.93 \pm 0.01$ & Undetected \\
FT & $1.15 \pm 0.01$ & $1.42 \pm 0.02$ & $0.38 \pm 0.01$ & $1.41 \pm 0.01$ & $4.00 \pm 0.02$ & $1.01 \pm 0.02$ & $1.47 \pm 0.01$ & $0.30 \pm 0.01$ \\
NG1 & $1.18 \pm 0.01$ & $1.2 \pm 0.01$ & $0.4 \pm 0.01$ & $1.36 \pm 0.02$ & $3.80 \pm 0.01$ & $1.01 \pm 0.01$ & $1.45 \pm 0.01$ & $0.21 \pm 0.01$ \\
KC & $1.20 \pm 0.01$ & $1.4 \pm 0.00$ & $0.35 \pm 0.01$ & $1.20 \pm 0.01$ & $3.50 \pm 0.02$ & $0.98 \pm 0.02$ & $1.35 \pm 0.01$ & $0.27 \pm 0.01$ \\
GS2 & $1.24 \pm 0.01$ & $1.40 \pm 0.03$ & $0.40 \pm 0.01$ & $1.42 \pm 0.02$ & $4.4 \pm 0.01$ & $1.0 \pm 0.04$ & $1.5 \pm 0.01$ & $0.30 \pm 0.01$ \\
AD1 & $1.24 \pm 0.01$ & $1.56 \pm 0.01$ & $0.38 \pm 0.01$ & $1.41 \pm 0.01$ & $4.42 \pm 0.02$ & $0.94 \pm 0.01$ & $1.49 \pm 0.01$ & $0.19 \pm 0.01$ \\
NG2 & $1.17 \pm 0.01$ & $1.3 \pm 0.01$ & $0.43 \pm 0.01$ & $1.37 \pm 0.01$ & $4.01 \pm 0.01$ & $0.92 \pm 0.01$ & $1.54 \pm 0.01$ & $0.20 \pm 0.01$ \\
SC8 & $1.27 \pm 0.01$ & $1.50 \pm 0.01$ & $0.36 \pm 0.01$ & $1.43 \pm 0.01$ & $3.97 \pm 0.01$ & $1.01 \pm 0.01$ & $1.57 \pm 0.01$ & $0.31 \pm 0.01$ \\
KB & $1.17 \pm 0.02$ & $1.50 \pm 0.01$ & $0.37 \pm 0.01$ & $1.45 \pm 0.01$ & $4.37 \pm 0.01$ & $0.88 \pm 0.01$ & $1.39 \pm 0.01$ & $0.25 \pm 0.01$ \\
GS & $1.27 \pm 0.01$ & $1.3 \pm 0.01$ & $0.41 \pm 0.01$ & $1.44 \pm 0.02$ & $4.86 \pm 0.01$ & $0.97 \pm 0.06$ & $1.5 \pm 0.01$ & $0.29 \pm 0.01$ \\
AD & $1.10 \pm 0.01$ & $1.15 \pm 0.01$ & Undetected & $1.1 \pm 0.01$ & $1.62 \pm 0.01$ & Undetected & $1.00 \pm 0.01$ & $0.00 \pm 0.00$ \\
ABK & $1.20 \pm 0.01$ & $1.60 \pm 0.02$ & $0.42 \pm 0.01$ & $1.38 \pm 0.01$ & $4.37 \pm 0.01$ & $0.91 \pm 0.01$ & $1.47 \pm 0.01$ & $0.20 \pm 0.00$ \\
GS1 & $1.20 \pm 0.02$ & $1.5 \pm 0.02$ & $0.40 \pm 0.01$ & $1.46 \pm 0.02$ & $4.20 \pm 0.01$ & $1.01 \pm 0.01$ & $1.5 \pm 0.00$ & $0.28 \pm 0.01$ \\
YB & $1.10 \pm 0.01$ & $1.3 \pm 0.01$ & $0.38 \pm 0.01$ & $1.20 \pm 0.01$ & $3.57 \pm 0.01$ & $0.89 \pm 0.01$ & $1.34 \pm 0.01$ & $0.31 \pm 0.01$ \\
YG & $1.20 \pm 0.01$ & $1.51 \pm 0.02$ & $0.35 \pm 0.01$ & $1.37 \pm 0.01$ & $4.07 \pm 0.02$ & $0.94 \pm 0.01$ & $1.41 \pm 0.01$ & $0.36 \pm 0.01$ \\
KR & $1.17 \pm 0.01$ & $1.41 \pm 0.01$ & $0.40 \pm 0.01$ & $1.39 \pm 0.01$ & $4.16 \pm 0.01$ & $0.97 \pm 0.01$ & $1.49 \pm 0.01$ & $0.34 \pm 0.01$ \\
SC9 & $1.30 \pm 0.01$ & $1.5 \pm 0.01$ & $0.40 \pm 0.01$ & $1.47 \pm 0.01$ & $4.09 \pm 0.01$ & $1.02 \pm 0.03$ & $1.54 \pm 0.02$ & $0.20 \pm 0.01$ \\
BK & $1.10 \pm 0.01$ & $1.21 \pm 0.01$ & Undetected & $1.12 \pm 0.01$ & $1.62 \pm 0.01$ & Undetected & $1.00 \pm 0.02$ & Undetected \\
\hline
\end{tabular}

Notes: Values are presented in means \pm standard deviation. 
FT are all closely related. NG1 and NG2 were clustered together showing similarities. $\mathrm{KC}$ and $\mathrm{YB}$ were also clustered together. The other cluster IIb consisted of two NACGRAB accessions (NG1 and NG2), two IAR accessions (SC9 and SC8), two from Dangote Ginnery (YB and $\mathrm{KC}$ ) and nine others obtained from the farmers' field. All of these have shown to be similar.
Neighbour Joining cluster showed that accession C8 and SC9 collected from the same research institute as closely related. It was revealed that accession $\mathrm{AD}$ and $\mathrm{BK}$ as of the same type and $\mathrm{KN}$ as close relative. The cluster revealed that NG1, a hybrid, was a neighbour to NG2, a hybrid. It also showed YG, KR and GS1 as neighbours, these are naturally occurring in the farmers' fields (Figure 2).

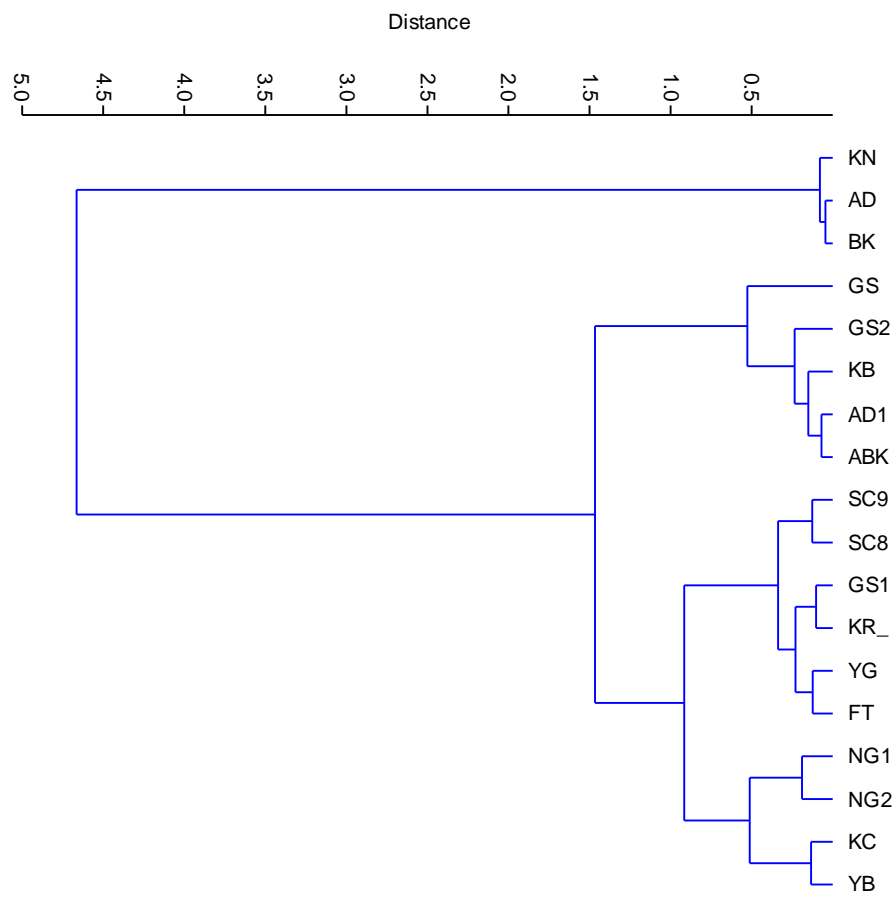

Figure 1. Dendrogram generated based on Ward's clustering method for phytochemical traits among 18 accessions of Gossypium hirsutum

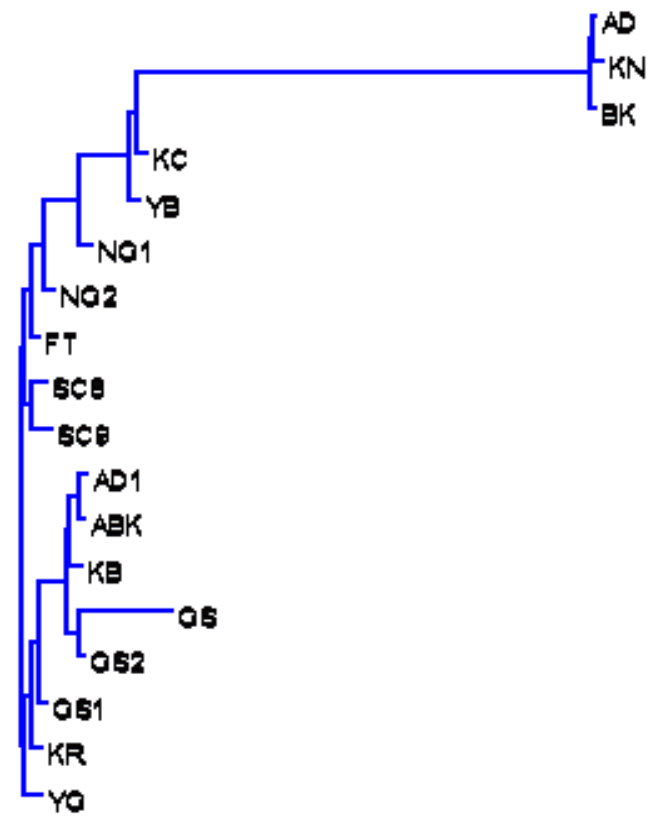

Figure 2. Neighbour Joining dendrogram for phytochemical traits among 18 accessions of Gossypium hirsutum 


\section{DISCUSSION}

The phytochemical profile obtained for G. hirsutum in this study was similar to the report of Ayeni et al. (2015) with an exception for terpenoids where it was reported to be absent. The absence could be attributed to the area of collection since samples were not collected from Ekiti. However, it differs from the report of Chandrashekar et al. (2013) which attempted to isolate the gossypol and screen the phytochemical constituents from G. hirsutum seed extract. The similarity of phytochemicals in the study further confirms the plants as emanating from the same family. This is supported by the work of Sharma and Kaur (2017) that proposed the categorisation of plants are based on the presence of similar phytochemical components.

Clustering of accessions together on the basis of phytochemical attributes showed that $\mathrm{KN}, \mathrm{BK}$ and $\mathrm{AD}$ are closely related although they are not from same geographic locations. GS1, GS2, KB, AD1 and $\mathrm{ABK}$ clustered together albeit they are from different zones. Accessions $\mathrm{AD} 1$ and $\mathrm{ABK}$ were found to be closely related to each other based on their phytochemical attributes. The clustering of accessions from different geographic locations together shows that the presence of certain phytochemical compounds and related substances is considered the traits of certain taxonomic group as indicated in Umoh (2020). This could be the basis for clustering together of accessions from different geographical zones. Thus, the relevance of phytochemical attributes in delimiting taxa. The clustering, also, of hybrid accessions with those collected from the field shows that phytochemical traits can be used for taxonomic purposes. This is supported by the work of Domingues et al. (1998) that elaborated on the use of secondary metabolites as indicator in determining taxonomic and phylogenetic relationship. The variations observed in the quality and quantity of phytochemicals present could be due to the instability of chemical compounds caused by environmental changes such as temperature or mineral deficiencies (Ben et al., 2018).

\section{CONCLUSION}

The results obtained from this study revealed that the presence of certain secondary metabolites is an indication of traits emanating from same species that could be useful for taxonomic purposes.
Temperature and mineral availability affect the quantity and quality of phytochemicals. Variations observed are considered to support plant chemical diversity. These variations are also of taxonomic value in resolving problems where relationships based on other evidence are conflicting.

\section{ACKNOWLEDGEMENTS}

This research was supported by a grant from the Nigerian Tertiary Education Trust Fund (Tetfund) to Dr Danzaki. The authors are thankful to the Institute of Agricultural Research (IAR), Zaria, Kaduna State, National Center for Genetic Research and Biotechnology (NACGRAB), Ibadan, Oyo State, Dangote Ginnery, Kankara, Katsina state, Nigeria for providing the hybrid accessions used for the research. We are also thankful to Professor AA Abdulrahaman, the Head of Department Plant Biology, University of Ilorin, Ilorin for allowing us to access the Herbarium and laboratories.

\section{REFERENCES}

Amadi, B.A., Agomuo, E.N. \& Ibegbulem, C.O. (2004). Research Methods in Biochemistry. Owerri: Supreme Publishers.

Akpabio, K.E. (1988). Crude protein electrophoresis of seeds of eight species of Crotalaria L. Nigeria Journal of Botany, 1: 106-110.

Atal, C. (1982). Cultivation and utilization of aromatic plants. 1st ed, New Delhi: Council of Scientific and Industrial Research. Pp 15-21.

Ayeni, M.J., Oyeyemi, S.D., Kayode, J. \& Peter, G. P. (2015). Phytochemical, proximate and mineral analyses of the Leaves of Gossypium hirsutum L. and Momordica charantia L. Journal of Natural Sciences Research, 5(6): 99-107.

Ben, A.A., Anakaa, T.M. \& Peters, G.C. (2017). Identification and taxonomic classification of plants in the family Portulacaceae in Dutsin-Ma local government area of Katsina State, Nigeria. International Journal of Innovative Research and Advanced Studies, 4(10): 146-149.

Boham, B.A. and Kocipal-Abyazan, R. (1994). Flanonoids and condensed tannins from leaves of Hawaiian Vaccinium reticulatum and V. calycinum. Pacific Science 48, Pp 458-463. 
Chandrashekar, R., Kumar, A.K., Reddy, Y. R., Chaitanya, P.J., Bhavani, N. L. \& Pochampalli, J. (2013). Isolation of gossypol and analysis of phytochemicals in seed extract of $\mathrm{Bt}$ and non-Bt varieties of cotton. Journal of Pharmacognosy and Phytochemistry, 2(1): 180-186.

Davis, P.A. \& Heywood, VH. (1963). Principle of Angiosperm Taxonomy. Edinburgh: Oliver and Boyd. Pp 210-230.

Domingues, R. M., Kaita, M. C., Avelar, E., Sonza, K.E.S., Moraes, W.D.G.S \& Franco, E.N. (1998). Electrophoretic characterization of exposed outer membrane proteins in environmental and human bacteroides fragilis strains. Zentralblatt für Bakteriologie, 287(4): 331-341.

Ejikeme, C. M., Ezeonu, C. S. \& Eboatu, A. N. (2014) Determination of physical and phytochemical constituents of some tropical timbers indigenous to Niger Delta Area of Nigeria. European Scientific Journal, 10(8): 247-270.

Feliner, G.N. \& Fernandez, I.A. (2000). Biosystematics in the 90s: Integrating data from different sources. Portugaliae Acta Biologica, 19: 9-19.

Harbourne, J. B. (1973). Phytochemical Methods. London: Chapman and Hall Ltd. Pp 49-188.

Harborne, J.B. (1993). Introduction to ecological biochemistry. London: Fourth Academic Press.

Hegnauer, R. (1986). Phytochemistry and plant taxonomy - An essay on the chemotaxonomy of higher plants. Phytochemistry, 25: 1519-1535.

Jones, B. and Luchsinger, A. (1987). Plant systematics. New York: Mc-Graw Hill Book Co.

Obadoni, B.O. \& Ochuko, P.O. (2001). Phytochemical studies and efficacy of the extracts of some haemostatic plants in Edo and Delta States of Nigeria. Global Journal of Pure and Applied Science, 8: 203208.

Odebiyi, A. \& Sofowora, A.E. (1990). Phytochemical screening of Nigerian Medicinal Plants (Part III). Lloyida, 14: 234-246.

Pandey, B.P. (2007). A Text Book of Botany: Angiosperms: Taxonomy, Anatomy, Embryology (Including Tissue Culture) and Economic Botany. Second Edition. New Delhi: S. Chand and Company Limited, Pp 990.
Singh, R. (2016). Chemotaxonomy: A tool for plant classification. Journal of Medicinal Plant Studies, 4(2): 90-93.

Smith, M. A., Rottkamp, C. A., Nunomura, A., Raina, A. K. \& Perry, G. (2000). Oxidative stress in Alzheimer's disease. Biochimica et Biophysica Acta-Molecular Basis of Disease, 1502(1): 139144.

Smith, P. (1976). The chemotaxonomy of plants London. London: Edward Arnold (Publishers) Ltd.

Sofowora, E. A. (1993). Medicinal plants and traditional medicine in Africa. Ibadan, Nigeria: Spectrum Books Limited. Pp.150 -289.

Sharma, R \& Kaur, S. (2017). Antimicrobial and phytochemical screening of Trikuta-traditional food of western Rajasthan. Indian Journal of Traditional Knowledge, 16(2): 270-276.

Sofowora, E. A. (1993). Medicinal plants and traditional medicine in Africa. Nigeria: Spectrum Books Limited, Pp.150 -289.

Stace, C. (1980). Plant Taxonomy and Biosystematics. London: Edward Arnold (Publishers) Ltd.

Trease, G.E. \& Evans, W.C. (1989). Pharmacognosy. Nigeria: Nigerian Tirldercan Macmillian Publishers.

Umoh, O. (2020). Chemotaxonomy: The role of phytochemicals in chemotaxonomic delineation of taxa. Asian Plant Research Journal, 5(1): 43-52.

Van-Burden, T. \& Robinson, W. (1969). Formation of complexes between protein and tannin acid. Journal of Agricultural Food Chemistry, 17(4):772-777.

Wink, M. and Waterman, P.G. (1999). Chemotaxonomy in relation to molecular phylogeny of plants. In Wink, M. and Waterman, P.G. (eds) Biochemistry of plant secondary metabolism. Sheffield Academic Press and CRC Press. Pp. 300-341.

Zheng, W. and Wang, S.Y. (2003). Oxygen Radical Absorbing Capacity of Flavonoids Phenolic Acids in Blueberry, Cranberry, Chokeberry and Liganberry. Journal of Agriculture and Food Chemistry, 51: 502509. 